\title{
Rebamipide does not protect against naproxen-induced gastric damage: a randomized double-blind controlled trial
}

Thiago Gagliano-Jucá ${ }^{*}$, Ronilson A. Moreno ${ }^{2}$, Tiago Zaminelli ${ }^{3}$, Mauro Napolitano ${ }^{4}$, Antônio Frederico N. Magalhães ${ }^{5}$, Aloísio Carvalhaes ${ }^{6}$, Miriam S. Trevisan ${ }^{5}$, John L. Wallace ${ }^{7}$ and Gilberto De Nucci $i^{3,7,8}$

\begin{abstract}
Background: Rebamipide is a gastroprotective agent with promising results against gastric damage induced by non-steroidal anti-inflammatory drugs. The present study evaluated if rebamipide protects against naproxen-induced gastric damage in healthy volunteers. Changes in gastric PGE2 tissue concentration were also evaluated.

Methods: After a preliminary endoscopy to rule out previous gastric macroscopic damage, twenty-four healthy volunteers of both sexes were divided into 2 groups. One group received sodium naproxen $550 \mathrm{mg}$ b.i.d. plus placebo for 7 days, while the other group received sodium naproxen $550 \mathrm{mg}$ b.i.d. plus rebamipide $100 \mathrm{mg}$ b.i.d. At the end of treatment, a new endoscopy was performed. Gastric macroscopic damage was evaluated by the Cryer score and by the modified Lanza score. The primary outcome measure of the trial was the macroscopic damage observed in each treatment group at the end of treatment. Biopsies were collected at both endoscopies for PGE2 quantification and histopathological analysis (secondary outcomes). Tissue PGE2 was quantified by ELISA. The randomization sequence was generated using 3 blocks of 8 subjects each. Volunteers and endoscopists were blind to whether they were receiving rebamipide or placebo.
\end{abstract}

Results: All recruited volunteers completed the trial. Sodium naproxen induced gastric damage in both groups. At the end of the study, median Cryer score was 4 in both groups (Difference $=0 ; 95 \% \mathrm{Cl}=-1$ to $0 ; p=0.728$ ). In the placebo group, the mean tissue PGE2 concentration was $1005 \pm 129 \mathrm{pg} / \mathrm{mL}$ before treatment and $241 \pm 41 \mathrm{pg} / \mathrm{mL}$ after treatment $(p<0.001)$. In the rebamipide group, the mean tissue PGE2 concentration was $999 \pm 109 \mathrm{pg} / \mathrm{mL}$ before treatment, and $168 \pm 13 \mathrm{pg} / \mathrm{mL}$ after treatment $(p<0.001)$. There was no difference in mean tissue PGE2 between the two groups (difference $=5 ; 95 \% \mathrm{Cl}$ from -334.870 to $345.650 ; p=0.975$ ). No significant change was observed at the histopathological evaluation, despite the evident macroscopic damage induced by naproxen.

Conclusion: Rebamipide does not protect against naproxen-induced gastric damage in healthy volunteers.

Trial registration: ClinicalTrials.gov, NCT02632812. Registered 14 December 2015.

Keywords: NSAID, Histopathology, Human, ELISA, Endoscopy, Cryer score, Modified Lanza score

\footnotetext{
*Correspondence: thiagogagliano@gmail.com

'Institute of Biophysics Carlos Chagas Filho, Federal University of Rio de

Janeiro (UFRJ), 21941-902 Rio de Janeiro, Brazil

Full list of author information is available at the end of the article
} 


\section{Background}

Naproxen and other non-selective non-steroidal antiinflammatory drugs (NSAIDs) induce gastrointestinal (GI) adverse events ranging from dyspepsia to upper and lower GI tract ulcers [1-3]. Naproxen 660 - 1000 mg per day administered for 2 to 14 days is used as a model for NSAID-induced gastroduodenal damage in healthy volunteers [4-8].

Rebamipide has been described as a GI mucosal protector agent with promising results in prophylaxis and treatment of GI ulcers caused by NSAIDs, $H$. pylori or endoscopic submucosal dissection [9-15]. Results from animal studies have suggested that the protective effects of rebamipide are attributable to stimulation of prostaglandin (PG) synthesis [16, 17]. In healthy volunteers, concomitant administration of rebamipide $100 \mathrm{mg}$ with ibuprofen $600 \mathrm{mg}$ t.i.d. for 7 consecutive days resulted in a mean gastric damage score of $1.3 \pm 1.0$, which was significantly lower than that of the control group (mean score of $2.9 \pm 1.7)$, as assessed by the modified Lanza score $(p=0.032)$ [10]. In patients with rheumatic disease rebamipide $100 \mathrm{mg}$ b.i.d. also showed a protective effect against NSAID-induced gastric damage [18].

The present study evaluated whether rebamipide could provide a protective effect against naproxen-induced gastric damage in healthy volunteers.

\section{Methods}

\section{Volunteers}

Volunteers of both sexes aged 18 years old or older without any significant cardiac, hepatic, renal, pulmonary, neurological, gastrointestinal or hematological diseases, as determined by their medical history, physical examination, and routine laboratory tests (hematology, blood biochemistry, urine analysis and fecal occult blood test), were invited to participate in this double-blind, randomized, parallel placebo-controlled phase II singlecenter trial. All subjects tested negative for hepatitis B and C (except for serologic scar), as well as HIV I and II, and were instructed to abstain from taking any medication including over-the-counter medication for 2 weeks prior to and during the study period. Pregnancy was an exclusion criterion. All women enrolled had negative $\beta$ HCG. All volunteers were informed about the aim and risks of the study by the clinical investigator and they all signed a written informed consent statement before entering the study. The study was performed according to the 2008 revised Declaration of Helsinki for bio-medical research involving human subjects and the 1996 rules of Good Clinical Practices. The study protocol was approved by the Committee of Research Ethics of the University of Sao Paulo, Sao Paulo, Brazil, on 26 November 2014 (before the initiation of the study procedures), and the study is registered at ClinicalTrials.gov, ID NCT02632812.
After performing a preliminary gastroduodenal endoscopy at the Vera Cruz Hospital (Campinas, Brazil) to rule-out prior macroscopic upper GI damage in the subjects, twenty-four healthy volunteers (12 men) were enrolled in the study. Other exclusion criteria were: achlorhydria $(\mathrm{pH}>6.5)$; positive fecal occult blood test; drug abuse, including alcohol or tobacco.

\section{Treatment}

Volunteers were randomly divided into 2 groups: group A received $550 \mathrm{mg}$ of sodium naproxen (Flanax ${ }^{\circ}$ - Bayer) plus an effervescent placebo (Biolab Indústria Farmacêutica Ltda.) diluted in $200 \mathrm{~mL}$ of water b.i.d. for 7 consecutive days; group B received $550 \mathrm{mg}$ of sodium naproxen (Flanax ${ }^{\oplus}$ - Bayer) plus $100 \mathrm{mg}$ of effervescent rebamipide (Biolab Indústria Farmacêutica Ltda.) diluted in $200 \mathrm{~mL}$ of water b.i.d. for 7 consecutive days. The randomization sequence was determined using the randomization generator available at www.randomization.com, using 3 blocks of 8 subjects each. Volunteers were blind to whether they were receiving rebamipide or placebo. To assure adherence, the drugs were administered by a member of the research team (also blind to treatment allocation) early in the morning and late in the evening for the whole duration of the study. A pharmacist was responsible for labeling treatments as A or B, and for breaking the code at the end of the study. Volunteers were required to be fasted in the morning and were only allowed to eat at least $2 \mathrm{~h}$ after administration of medications. In the evening, volunteers were required to be at least for $2 \mathrm{~h}$ without ingestion of food, and were also asked to avoid eating for the following $2 \mathrm{~h}$ after the dose.

Adverse reactions were individually evaluated. Causality relationship to the treatment was assessed with the aid of the Karch \& Lasagna algorithm [19]. The necessity of interruption of treatment or specific therapy was individually assessed by the Principal Investigator depending on the severity of the reaction and the causality relationship to the treatment.

\section{Gastrointestinal damage evaluation}

Gastroduodenal endoscopy was performed before the start of the study and in the morning of the 8th day of treatment in all volunteers. Exams were performed by a single endoscopist. The primary outcome measure of the trial was the macroscopic damage observed in each treatment group at the end of treatment. The number of mucosal erosions after treatment was counted and macroscopic mucosal injury scored according to Cryer [20] and to the modified Lanza score (MLS; Table 1) $[9,21]$. Gastroduodenal ulcers were classified according to the Sakita-Miwa classification. Additionally, a second endoscopist retrospectively evaluated the exams, blind to 
Table 1 Cryer and modified Lanza scores according to gastroduodenal mucosal injury

\begin{tabular}{|c|c|c|}
\hline Score & Cryer score & Modified Lanza score \\
\hline 0 & Normal or erythema & $\begin{array}{l}\text { No hemorrhage or erosion } \\
\text { observed }\end{array}$ \\
\hline 1 & $\begin{array}{l}\text { Any amount of submucosal } \\
\text { hemorrhage or edema without } \\
\text { erosions. }\end{array}$ & $\begin{array}{l}\text { One or two hemorrhages or } \\
\text { erosions observed in one } \\
\text { gastric area. }\end{array}$ \\
\hline 2 & $\begin{array}{l}1 \text { erosion } \pm \text { submucosal } \\
\text { hemorrhage or edema. }\end{array}$ & $\begin{array}{l}\text { Three to five hemorrhages or } \\
\text { erosions observed in one } \\
\text { gastric area. }\end{array}$ \\
\hline 3 & $\begin{array}{l}2-4 \text { erosions } \pm \text { submucosal } \\
\text { hemorrhage or edema. }\end{array}$ & $\begin{array}{l}\text { Hemorrhages or erosions } \\
\text { observed in two gastric areas; } \\
\text { six or more hemorrhages or } \\
\text { erosions observed in one } \\
\text { gastric area, with the total } \\
\text { number not exceeding ten in } \\
\text { the entire stomach. }\end{array}$ \\
\hline 4 & $\begin{array}{l}5 \text { or more erosions and/or a } \\
\text { single ulcer } \pm \text { submucosal } \\
\text { hemorrhage or edema. }\end{array}$ & $\begin{array}{l}\text { Hemorrhages or erosions } \\
\text { observed in three or more } \\
\text { gastric areas; eleven or more } \\
\text { hemorrhages or erosions } \\
\text { observed widely in the entire } \\
\text { stomach. }\end{array}$ \\
\hline 5 & $\begin{array}{l}\text { Multiple ulcers } \pm \text { submucosal } \\
\text { hemorrhage or edema. }\end{array}$ & Ulcer. \\
\hline
\end{tabular}

the scores given by the first endoscopist. If there was any difference between the score given by the two endoscopists, the final score would be the mean value of the two numbers. Both endoscopists were blind to treatment group allocation of volunteers. In each exam 3 biopsies were collected from the gastric antrum and 3 from the gastric corpus for PGE2 quantification. Samples were immediately washed in phosphate buffer saline at $\mathrm{pH} 7.4$ and stored individually in a dry Eppendorf tube and kept at $-20{ }^{\circ} \mathrm{C}$ until analysis. Another 2 biopsies from each stomach region (4 total) were collected at each endoscopic procedure for histological analysis. Volunteers were questioned about GI symptoms at every dose. Changes in gastric PGE2 concentration, histopathological characteristics and GI symptoms at the end of the study compared to baseline were evaluated as secondary outcome measures. A more detailed questionnaire about GI symptoms such as heartburn, abdominal pain, fullness, nausea, vomiting, blood in stools or others was completed before receiving the first dose and at the last day of treatment. In the questionnaires, when any symptom was reported, the volunteer was asked to describe the intensity and frequency of the symptom over the previous 7 days. Routine laboratory tests were repeated at the end of treatment, including fecal occult blood test.

\section{PGE2 quantification}

Tissue PGE2 concentration was quantified by enzymelinked immunosorbent assay (ELISA) using Cayman
Chemical Monoclonal Prostaglandin $E_{2}$ EIA Kit (item number 514010). Briefly, biopsies from the gastric antrum and corpus collected in both endoscopic procedures were weighted and homogenized individually for $20 \mathrm{~s}$ by a Polytron in $1 \mathrm{~mL}$ of $\mathrm{Na}_{3} \mathrm{PO}_{4}$ buffer solution $(\mathrm{pH}=7.4)$. Aliquots of $200 \mu \mathrm{L}$ of the homogenate were placed in a dry bath at $37{ }^{\circ} \mathrm{C}$ for $20 \mathrm{~min}$ and then centrifuged at $20,800 \mathrm{~g}$ for $30 \mathrm{~s}$. Supernatant $(150 \mu \mathrm{L})$ was collected and diluted 1:100 (v/v) to be used in the ELISA. Each aliquot was assayed in duplicate and final PGE2 concentrations were adjusted for initial sample mass. Data are displayed as mean \pm SEM. The person responsible for the quantification of PGE2 was blind to treatment group allocation of volunteers.

\section{Histopathological evaluation}

Biopsies from gastric antrum and corpus were immediately put in formaldehyde after collection. Samples were stained in hematoxylin and eosin for characterization and graded according to a score described in Table 2 . Giemsa stain was used to diagnose $H$. pylori infection. The pathologist was also blind to treatments.

\section{Statistical analysis}

For evaluation of statistical difference of tissue PGE2 between treatments, a $t$-test was performed. A paired $t$ test was used to compare tissue PGE2 before and after treatments within each group. Endoscopic and histopathological scores between treatment groups were compared using the Mann-Whitney $U$-test. Gastrointestinal symptoms after treatments were compared by Fisher's exact test. A p value $<0.05$ was considered significant. The sample size planned for the study was 24 volunteers of both sexes. This number was chosen based on the gastroprotective effects of rebamipide previously reported [9]. The calculation considered the Mann-Whitney $U$ test analysis of the reported data on gastroduodenal damage scoring by MLS. The effect size observed (difference between treatments) was $67 \%$ (median score after treatment of 3 and 1, in the placebo and rebamipide groups, respectively). Given a power of $80 \%$ and a 0.05 chance of type 1 error, the original sample size estimation was 10 volunteers per group. The final number of 12 volunteers per group was chosen considering a $20 \%$ rate of drop-out. Other studies with rebamipide in healthy volunteers also used similar sample sizes [10, 15].

\section{Results}

All 24 volunteers enrolled completed all procedures of the study. The median age of men was 24 years (range 18 49 years), mean weight was $75.7 \mathrm{~kg}(61.0-97.0 \mathrm{~kg})$, mean height was $175 \mathrm{~cm}(152-186 \mathrm{~cm})$, and mean body mass index was $24.8 \mathrm{~kg} / \mathrm{m}^{2}\left(20.2-28.7 \mathrm{~kg} / \mathrm{m}^{2}\right)$. Women had a 
Table 2 Histhopathologic grade score developed for microscopic injury evaluation

\begin{tabular}{ll}
\hline Score & Findings \\
\hline 0 & Normal gastric mucosa or mild chronic inflammation \\
1 & Chronic gastritis without activity \\
2 & Chronic gastritis with activity on antrum \\
3 & Chronic gastritis with activity on the body \\
4 & Chronic gastritis with activity on antrum and on the body \\
\hline
\end{tabular}

median age of 24.5 years (range 20 - 42 years), mean weight was $69.5 \mathrm{~kg}(54.0$ - $83.0 \mathrm{~kg})$, mean height was $164 \mathrm{~cm}(153-170 \mathrm{~cm})$, and mean body mass index was $25.9 \mathrm{~kg} / \mathrm{m}^{2}\left(20.7-28.7 \mathrm{~kg} / \mathrm{m}^{2}\right)$. Three volunteers (two men) were not allowed to enroll in the study because of gastric damage observation in the preliminary endoscopy.
There was agreement between the endoscopists on the scores of all exams. Endoscopic findings and scores for each volunteer using the macroscopic scoring systems are summarized in Table 3. The median Cryer score was 4 in both placebo and rebamipide groups (Difference $=0$; $95 \% \mathrm{CI}=-1$ to $0 ; p=0.728)$. The median MLS was 4 in the placebo group and 3.5 in the rebamipide group (Difference $=0.5 ; 95 \% \mathrm{CI}=-2$ to $1 ; p=0.822$ ). In the placebo group 2 volunteers (16\%) presented GI ulcers (1 ulcer each), while 4 volunteers (32\%) in the rebamipide group had ulcers $(p=0.320)$. Figure 1a and $b$ illustrate the macroscopic aspect of the gastric mucosa of volunteer 24 in the rebamipide group before treatment and at the end of the study.

The incidence of GI symptoms in each treatment group is displayed in Table 4. Individual data regarding

Table 3 Summary of findings in the endoscopic procedure at the end of treatments

\begin{tabular}{|c|c|c|c|c|c|c|c|}
\hline $\begin{array}{l}\text { Volunteer } \\
\#\end{array}$ & Treatment & $\begin{array}{l}\text { Scores before } \\
\text { treatment }\end{array}$ & $\begin{array}{l}\text { Cryer } \\
\text { Score }\end{array}$ & $\begin{array}{l}\text { Lanza } \\
\text { Score }\end{array}$ & Antrum & Duodenum & Other \\
\hline 2 & Placebo & 0 & 3 & 2 & 4 erosions & & \\
\hline 5 & Placebo & 0 & 2 & 1 & $\begin{array}{l}1 \text { erosion + submucousal } \\
\text { hemorrage }\end{array}$ & & \\
\hline 7 & Placebo & 0 & 4 & 4 & $>20$ erosions & & \\
\hline 8 & Placebo & 0 & 4 & 5 & $\begin{array}{l}2 \text { erosions + } 1 \text { ulcer } \\
\text { (Sakita } A 2)\end{array}$ & & \\
\hline 10 & Placebo & 0 & 4 & 4 & $>10$ erosions & & \\
\hline 12 & Placebo & 0 & 4 & 5 & $\begin{array}{l}10 \text { erosions }+1 \text { ulcer } \\
\text { (Sakita } A 2)\end{array}$ & & \\
\hline 14 & Placebo & 0 & 4 & 2 & 5 erosions & & \\
\hline 16 & Placebo & 0 & 4 & 4 & 20 erosions & & \\
\hline 17 & Placebo & 0 & 4 & 4 & 10 erosions & 3 erosions & \\
\hline 18 & Placebo & 0 & 4 & 4 & 10 erosions & & \\
\hline 19 & Placebo & 0 & 4 & 4 & 10 erosions & & \\
\hline 23 & Placebo & 0 & 4 & 4 & 10 erosions & & \\
\hline 1 & Rebamipide & 0 & 4 & 4 & 20-25 erosions & & \\
\hline 3 & Rebamipide & 0 & 4 & 4 & 10 erosions & & \\
\hline 4 & Rebamipide & 0 & 4 & 5 & 10 erosions & $\begin{array}{l}1 \text { ulcer } \\
\text { (Sakita A2) }\end{array}$ & \\
\hline 6 & Rebamipide & 0 & 3 & 1 & 2 erosions + erythema & & \\
\hline 9 & Rebamipide & 0 & 3 & 2 & 3 erosions & & \\
\hline 11 & Rebamipide & 0 & 3 & 3 & 2 erosions & & $\begin{array}{l}\text { Submucousal hemorrhage in } \\
\text { gastric fundus }\end{array}$ \\
\hline 13 & Rebamipide & 0 & 5 & 5 & $\begin{array}{l}\text { Small erosions }+2 \text { ulcers } \\
\text { (Sakita A2) }\end{array}$ & & \\
\hline 15 & Rebamipide & 0 & 4 & 2 & 5 erosions + erythema & & \\
\hline 20 & Rebamipide & 0 & 3 & 2 & 4 erosions & & \\
\hline 21 & Rebamipide & 0 & 4 & 5 & & & $\begin{array}{l}\text { Pylorus with edema and } 1 \text { ulcer } \\
\text { (Sakita A2) }\end{array}$ \\
\hline 22 & Rebamipide & 0 & 3 & 2 & 3 erosions & & \\
\hline 24 & Rebamipide & 0 & 5 & 5 & $\begin{array}{l}10 \text { erosions }+4 \text { ulcers } \\
(\text { Sakita } \mathrm{A} 2)\end{array}$ & & \\
\hline
\end{tabular}



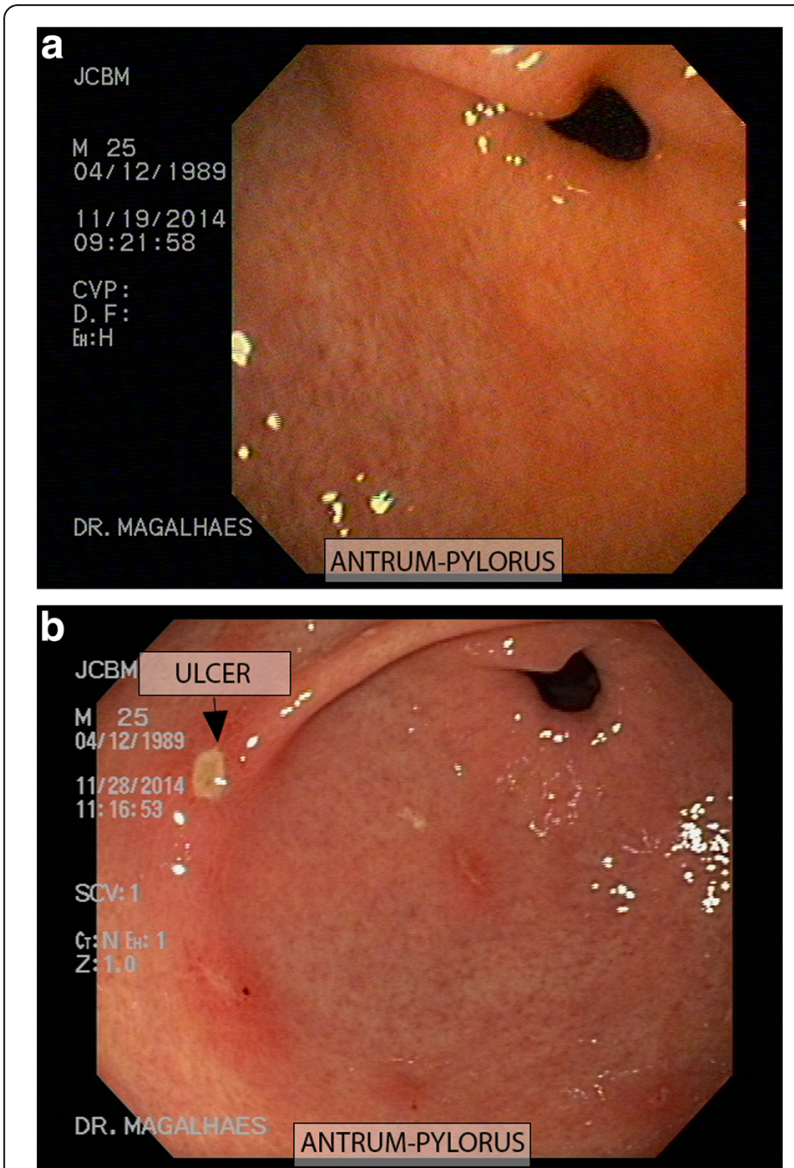

Fig. 1 Photographic documentation of the endoscopic procedure in a volunteer in the rebamipide group (a) before and (b) after treatment

GI symptoms is available in Additional file 1: Table S1. There were no statistical differences between treatment groups at the end of the study. All fecal occult blood tests were negative at the end of treatment.

\section{PGE2 quantification}

In the placebo group, the mean tissue PGE2 concentration was $1005 \pm 129 \mathrm{pg} / \mathrm{mL}$ before treatment, and $241 \pm$ $41 \mathrm{pg} / \mathrm{mL}$ after treatment (difference $=764 ; 95 \% \mathrm{CI}$ from 477 to 1051), which corresponded to a mean inhibition of PGE2 synthesis of $76.0 \%(p<0.001)$. In the rebamipide group, the mean tissue PGE2 concentration was $999 \pm 109 \mathrm{pg} / \mathrm{mL}$ before treatment, and $168 \pm 13 \mathrm{pg} / \mathrm{mL}$ after treatment $($ difference $=831.5 ; 95 \% \mathrm{CI}$ from 612 to 1051), a mean inhibition of $83.2 \%(p<0.001)$. There was no difference between the two groups in PGE2 tissue concentration before treatments (difference $=5$; $95 \%$ CI from -334.870 to $345.650 ; p=0.975)$. The individual PGE2 concentration found for each volunteer before and after treatment is available in Additional file 2: Table S2.
Table 4 Incidence of gastrointestinal symptoms

\begin{tabular}{|c|c|c|c|c|c|c|}
\hline \multirow{2}{*}{$\begin{array}{l}\text { Gastrointestinal } \\
\text { symptom }\end{array}$} & \multicolumn{2}{|c|}{ Placebo $(n=12)$} & \multicolumn{2}{|c|}{ Rebamipide $(n=12)$} & \multicolumn{2}{|l|}{$P$ value } \\
\hline & Before & After & Before & After & Before & After \\
\hline Any & 3 & 5 & 5 & 3 & 0.67 & 0.33 \\
\hline Abdominal pain & 2 & 3 & 3 & 2 & 0.50 & 0.50 \\
\hline Heartburn & 2 & 2 & 3 & 1 & 0.50 & 0.50 \\
\hline Nausea & 1 & 2 & 1 & 1 & 0.76 & 0.50 \\
\hline Intestinal cramps & 0 & 1 & 1 & 0 & 0.50 & 0.50 \\
\hline Fullness & 1 & 0 & 0 & 0 & 0.50 & 1.00 \\
\hline
\end{tabular}

Incidence of gastrointestinal symptoms in each treatment group before the beginning and at the end of the study. $P$ value was calculated comparing incidence of symptoms between placebo and rebamipide groups before and after treatments by Fisher's exact test

\section{Histopathological evaluation}

At the initial endoscopic procedure, median histopathological scores were 1 in both groups (Difference $=0$; $95 \% \mathrm{CI}=-3$ to $1 ; p=0.582$ ). At the end of the study, median histopathological scores were also 1 in both groups (Difference $=0 ; 95 \% \mathrm{CI}=-1$ to $1 ; p=0.997$ ). At the initial endoscopy, 5 volunteers in each group were $H$. pylori positive. At the end of treatments, 6 subjects in each group were $H$. pylori positive. The individual histopathological score for each patient as well as $H$. pylori status before and after treatment is available in Additional file 3: Table S3.

\section{Discussion}

The present study did not find any evidence of a gastroprotective effect of rebamipide on naproxen-induced gastroduodenal damage as assessed by endoscopic macroscopic evaluation. This result differs from previous findings, in which rebamipide treatment resulted in less severe gastric damage induced by NSAIDs $[9,10,15]$. One possible explanation for the different results found in the present work is that naproxen was more aggressive than others models of NSAID-induced gastric damage. To evaluate this possibility, previously published data was further analyzed. Treatment with indomethacin at $75 \mathrm{mg} /$ day without rebamipide for 7 consecutive days resulted in a median MLS of 3 . When treatment was associated with rebamipide $100 \mathrm{mg}$ t.i.d., median MLS was 1 [9]. Treatment with ibuprofen $1800 \mathrm{mg} /$ day for $7 \mathrm{con}$ secutive days without rebamipide resulted in a median MLS of 3. When volunteers received rebamipide concomitantly with ibuprofen, median MLS was 2 [10]. By performing the Mann-Whitney $U$-test to compare MLS scores from the placebo group in the present study to those found in the placebo groups of the previously mentioned studies, no difference in gastric lesion scores among these 3 models of NSAID-induced gastric damage was observed (indomethacin vs. naproxen, $p=0.475$; ibuprofen vs. naproxen, $p=0.343$; indomethacin vs. ibuprofen, $p=1.0)$. However, since the characteristics of 
volunteers enrolled in the aforementioned studies are very different from those of the present study and trials designs are not the same, final conclusions cannot be drawn from these statistical analyses.

Since all the aforementioned studies evaluated Japanese or Korean subjects [9, 10, 13, 15, 18], population characteristics may have influenced the results. Higher gastric $\mathrm{pH}$ is known to be a protective factor in NSAIDinduced gastric damage. The incidence of hypochlorhydria in the Japanese population is higher than in western countries, affecting more than $40 \%$ of individuals over 50 year olds in Japan [22], while in the Unites States the incidence varies from $8 \%$ in young adults to $11 \%$ in the elderly [23, 24]. The higher gastric $\mathrm{pH}$ might facilitate the observation of the protective effect of rebamipide reported in Asian individuals. Another possibility for differences in rebamipide effects in NSAID-induced gastric damage is the genetic and dietary characteristics of the populations evaluated in each study.

One difference of the present study is that the daily dose of rebamipide was $200 \mathrm{mg}$, while most previous reports treated volunteers with $300 \mathrm{mg}$ of rebamipide per day [9-15, 25, 26]. However, rebamipide at $200 \mathrm{mg} /$ day in patients with rheumatic disease showed a protective effect in NSAID-induced gastroduodenal mucosal injury [18]. It is unlikely that a reduction in $33 \%$ of the dose would abolish the supposed effect of rebamipide. A lower dosage of rebamipide was chosen due to safety concerns. Most of the safety data about rebamipide comes from studies in Asian populations. This is the first time a study evaluated effects of rebamipide in a Brazilian population.

Increased PG synthesis was previously suggested as a possible mechanism for mucosal protection of rebamipide $[16,17]$. If so, rebamipide should not have a protective effect in NSAID-induced gastric damage through modulation of PG synthesis, since NSAIDs block the activity of cyclooxygenases.

In the present study, no significant histopathological change of the gastric mucosa was seen at the end of treatment in neither groups, despite the clear aggressiveness of naproxen observed on macroscopy. These results confirm previous reports that identified the histological features characteristic of NSAID users only in a subset of patients, and that microscopic findings do not correlate with macroscopical damage [27, 28]. This may reflect that the histological parameters used lack sufficient sensitivity or else, the mechanism responsible for the appearance of erosions and ulcers is independent of the degree of inflammation.

\section{Conclusion}

Rebamipide $200 \mathrm{mg} /$ day does not protect against naproxen-induced gastroduodenal damage in healthy volunteers.

\section{Additional files}

Additional file 1: Table S1. Gastrointestinal symptoms occurrence in the previous 7 days as reported by each volunteer before the initiation and at the end of treatments. (DOCX $17 \mathrm{~kb}$ )

Additional file 2: Table S2. Individual PGE2 concentration found at each assay for each gastric biopsy of each region evaluated, before and after treatment, for each volunteer. (DOCX 19 kb)

Additional file 3: Table S3. Individual histopathological scores and $\mathrm{H}$. pylori status before and after treatment for each volunteer. (DOCX $15 \mathrm{~kb}$ )

\section{Abbreviations}

ELISA, Enzyme-linked immunosorbent assay; Gl, Gastrointestinal; MLS, Modifies Lanza score; NSAIDs, Non-steroidal anti-inflammatory drugs; PG, Prostaglandin.

\section{Acknowledgements}

Not applicable.

Funding

The study was funded by Biolab Indústria Farmacêutica Ltda. The funding body approved the study design and the methods that were used for data acquisition and analysis, but had no involvement with the interpretation of data or with the composition of the manuscript.

Availability of data and materials

All the data supporting the findings of the study is contained within the manuscript and its supplementary files.

\section{Authors' contributions}

TGJ and GDN designed the research; TGJ, RAM, TZ, MN, AFNM, AC and MST performed the research; TGJ, RAM, TZ, MN, AFNM, AC, MST, JLW and GDN analyzed the data; TGJ, JLW and GDN wrote the paper. All authors read and approved the final manuscript.

\section{Authors' information}

Not applicable.

\section{Competing interests}

The authors declare that they have no competing interests.

\section{Consent for publication}

Written consent to publish the identifiable information and the images of the volunteer's endoscopic procedures, as well as the identifiable information of the endoscopist that performed the exams were obtained.

Ethics approval and consent to participate

The study protocol was approved by the Committee of Research Ethics of the University of Sao Paulo, Sao Paulo, Brazil (approval number 809.508). All study subjects gave written informed consent before entering the study.

\section{Author details}

${ }^{1}$ Institute of Biophysics Carlos Chagas Filho, Federal University of Rio de Janeiro (UFRJ), 21941-902 Rio de Janeiro, Brazil. ' Galeno Research Unit, Campinas, Brazil; Faculty of Medical Sciences, Metropolitan University of Santos, Santos, Brazil. ${ }^{3}$ Department of Pharmacology, Faculty of Medical Sciences, State University of Campinas (UNICAMP), Campinas, Brazil.

${ }^{4}$ Department of Pharmacology, ICB - University of Sao Paulo (USP), 05508-900 Sao Paulo, Brazil. ${ }^{5}$ Department of Gastroenterology, Faculty of Medical Sciences, State University of Campinas (UNICAMP), Campinas, Brazil. ${ }^{6}$ Brazilian Society for Digestive Endoscopy (SOBED), Sao Paulo, Brazil.

7Unicastelo Medical School, University Camilo Castelo Branco (UNICASTELO), Fernandopolis, Brazil. ${ }^{8}$ Department of Pharmacology, ICB - University of Sao Paulo (USP), Sao Paulo, Brazil.

Received: 26 November 2015 Accepted: 27 May 2016

Published online: 04 June 2016 


\section{References}

1. Wolfe MM, Lichtenstein DR, Singh G. Gastrointestinal toxicity of nonsteroidal antiinflammatory drugs. N Engl J Med. 1999;340(24):1888-99. doi:10.1056/ NEJM199906173402407.

2. Maiden L, Thjodleifsson B, Theodors A, Gonzalez J, Bjarnason I. A quantitative analysis of NSAID-induced small bowel pathology by capsule enteroscopy. Gastroenterology. 2005;128(5):1172-8.

3. Sostres C, Gargallo CJ, Arroyo MT, Lanas A. Adverse effects of non-steroidal anti-inflammatory drugs (NSAIDs, aspirin and coxibs) on upper gastrointestinal tract. Best Pract Res Clin Gastroenterol. 2010;24(2):121-32. doi:10.1016/j.bpg.2009.11.005.

4. Aadland E, Fausa O, Vatn M, Cohen H, Quinlan D. Protection by misoprostol against naproxen-induced gastric mucosal damage. Am J Med. 1987;83(1A):37-40.

5. Aabakken L, Osnes M. Gastroduodenal lesions induced by naproxen. An endoscopic evaluation of regional differences and natural course. Scand J Gastroenterol. 1990;25(12):1215-22.

6. Oddsson E, Gudjonsson H, Thjodleifsson B. Comparison between ranitidine and omeprazole for protection against gastroduodenal damage caused by naproxen. Scand J Gastroenterol. 1992;27(12):1045-8.

7. Sarosiek J, Marcinkiewicz M, Parolisi S, Peura DA. Prostaglandin E2 content in residual gastric juice reflects endoscopic damage to the gastric mucosa after naproxen sodium administration. Am J Gastroenterol. 1996;91(5):873-8.

8. Bianchi Porro G, Lazzaroni M, Petrillo M. Double-blind, double-dummy endoscopic comparison of the mucosal protective effects of misoprostol versus ranitidine on naproxen-induced mucosal injury to the stomach and duodenum in rheumatic patients. Am J Gastroenterol. 1997;92(4):663-7.

9. Naito Y, Yoshikawa T, linuma S, Yagi N, Matsuyama K, Boku Y, et al. Rebamipide protects against indomethacin-induced gastric mucosal injury in healthy volunteers in a double-blind, placebo-controlled study. Dig Dis Sci. 1998:43(9 Suppl):83S-9S.

10. Kim HK, Kim Jl, Kim JK, Han JY, Park SH, Choi KY, et al. Preventive effects of rebamipide on NSAID-induced gastric mucosal injury and reduction of gastric mucosal blood flow in healthy volunteers. Dig Dis Sci. 2007;52(8): 1776-82. doi:10.1007/s10620-006-9367-y.

11. Terano A, Arakawa T, Sugiyama T, Suzuki H, Joh T, Yoshikawa T, et al. Rebamipide, a gastro-protective and anti-inflammatory drug, promotes gastric ulcer healing following eradication therapy for Helicobacter pylori in a Japanese population: a randomized, double-blind, placebo-controlled trial. J Gastroenterol. 2007;42(8):690-3. doi:10.1007/s00535-007-2076-2.

12. Kobayashi M, Takeuchi M, Hashimoto S, Mizuno K, Sato $Y$, Narisawa $R$, et al. Contributing factors to gastric ulcer healing after endoscopic submucosal dissection including the promoting effect of rebamipide. Dig Dis Sci. 2012; 57(1):119-26. doi:10.1007/s10620-011-1850-4

13. Kim JH, Park SH, Cho CS, Lee ST, Yoo WH, Kim SK, et al. Preventive efficacy and safety of rebamipide in nonsteroidal anti-inflammatory drug-induced mucosal toxicity. Gut Liver. 2014;8(4):371-9. doi:10.5009/gnl.2014.8.4.371.

14. Kurokawa S, Katsuki S, Fujita T, Saitoh Y, Ohta H, Nishikawa K, et al. A randomized, double-blinded, placebo-controlled, multicenter trial, healing effect of rebamipide in patients with low-dose aspirin and/or non-steroida anti-inflammatory drug induced small bowel injury. J Gastroenterol. 2014; 49(2):239-44. doi:10.1007/s00535-013-0805-2

15. Tozawa K, Oshima T, Okugawa T, Ogawa T, Ohda Y, Tomita T, et al. A randomized, double-blind, placebo-controlled study of rebamipide for gastric mucosal injury taking aspirin with or without clopidogrel. Dig Dis Sci. 2014:59(8):1885-90. doi:10.1007/s10620-014-3108-4.

16. Kleine A, Kluge S, Peskar BM. Stimulation of prostaglandin biosynthesis mediates gastroprotective effect of rebamipide in rats. Dig Dis Sci. 1993; 38(8):1441-9.

17. Qi Z, Jie L, Haixia C, Xiaoying Z. Effect of rebamipide on quality of peptic ulcer healing in rat. Dig Dis Sci. 2009;54(9):1876-83. doi:10.1007/ s10620-008-0577-3.

18. Seo Yl, Park SH, Min DJ, Kim WU, Min JK, Lee SH, et al. Effects of rebamipide against nonsteroidal anti-inflammatory drugs (NSAIDs)induced gastroduodenal mucosal injury. J Korean Rheum Assoc. 2001;8(2):73-80.

19. Karch FE, Lasagna L. Toward the operational identification of adverse drug reactions. Clin Pharmacol Ther. 1977:21(3):247-54.

20. Cryer B, Feldman M. Effects of very low dose daily, long-term aspirin therapy on gastric, duodenal, and rectal prostaglandin levels and on mucosal injury in healthy humans. Gastroenterology. 1999;117(1):17-25.

21. Lanza FL, Royer Jr GL, Nelson RS, Chen TT, Seckman CE, Rack MF. A comparative endoscopic evaluation of the damaging effects of nonsteroidal anti-inflammatory agents on the gastric and duodenal mucosa. Am J Gastroenterol. 1981;75(1):17-21.

22. Morihara M, Aoyagi N, Kaniwa N, Kojima S, Ogata H. Assessment of gastric acidity of Japanese subjects over the last 15 years. Biol Pharm Bull. 2001; 24(3):313-5.

23. Dressman JB, Berardi RR, Dermentzoglou LC, Russell TL, Schmaltz SP, Barnett $J$, et al. Upper gastrointestinal $(\mathrm{Gl}) \mathrm{pH}$ in young, healthy men and women. Pharm Res. 1990;7(7):756-61.

24. Russell TL, Berardi RR, Barnett JL, Dermentzoglou LC, Jarvenpaa KM, Schmaltz SP, et al. Upper gastrointestinal pH in seventy-nine healthy, elderly, North American men and women. Pharm Res. 1993:10(2):187-96.

25. Talley NJ, Riff DS, Schwartz H, Marcuard SP. Double-blind placebo-controlled multicentre studies of rebamipide, a gastroprotective drug, in the treatment of functional dyspepsia with or without Helicobacter pylori infection. Aliment Pharmacol Ther. 2001:15(10):1603-11.

26. Mizukami K, Murakami K, Hirashita Y, Hisamatsu A, Ogawa R, Uchida M, et al. Efficacy of rebamipide for low-dose aspirin-related gastrointestinal symptoms. J Clin Biochem Nutr. 2012;51(3):216-20. doi:10.3164/jcbn.12-27.

27. El-Zimaity HM, Genta RM, Graham DY. Histological features do not define NSAID-induced gastritis. Hum Pathol. 1996;27(12):1348-54.

28. Frezza M, Gorji N, Melato M. The histopathology of non-steroidal antiinflammatory drug induced gastroduodenal damage: correlation with Helicobacter pylori, ulcers, and haemorrhagic events. J Clin Pathol. 2001; 54(7):521-5.

\section{Submit your next manuscript to BioMed Central and we will help you at every step:}

- We accept pre-submission inquiries

- Our selector tool helps you to find the most relevant journal

- We provide round the clock customer support

- Convenient online submission

- Thorough peer review

- Inclusion in PubMed and all major indexing services

- Maximum visibility for your research

Submit your manuscript at www.biomedcentral.com/submit 